\title{
REVIEW
}

\section{Two Reasons to Demonstrate Why American Beverage and Individu- alism Investments Should Be Welcomed}

\section{Yao Tong ${ }^{*}$}

Dongbei University of Finance and Economics, Dalian, Liaoning, 116025, China

\begin{tabular}{|c|c|}
\hline ARTICLE INFO & ABSTRACT \\
\hline Article history & In recent years, the Chinese beverage market has become more mature \\
\hline Received: 23 September 2019 & and customers have changed their priorities when buying drinks. Fur- \\
\hline Revised: 27 September 2019 & $\begin{array}{l}\text { thermore, Chinese people who are more likely to focus on group interests } \\
\text { tend to have more collectivism. The purpose of this article is to analyze }\end{array}$ \\
\hline Accepted: 24 October 2019 & the reasons why the investments of American beverage corporates and the \\
\hline Published Online: 31 October 2019 & $\begin{array}{l}\text { American individualism should be welcomed. The findings are (1) Co- } \\
\text { ca-Cola Company have more strengths and opportunities than weakness- }\end{array}$ \\
\hline Keywords: & es when they advertise in China; (2) the carbonated industry is predicted \\
\hline Carbonated industry & to have a not very bright future; (3) the methods that American beverage \\
\hline Coca-Cola & advocacies and CSR awareness; (4) American individualism can push \\
\hline CSR & Chinese employees to be more competent. \\
\hline
\end{tabular}

Individualism

Consumer culture theory

Pepsi

Starbucks

Advertising

Irreverence

\section{Introduction}

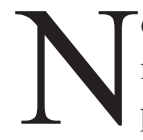

owadays, the situation of drinks is not very optimistic. Weird drinks have become more and more popular these days because customers are becoming more and more individualistic and paying attention to personal needs and preferences. ${ }^{[20]}$ Moreover, although the beverage market is full of new products, the product life cycle is getting shorter. Because the Chinese beverage industry is mature, the survival rate for new beverages has dropped to $5 \%$, which is less possible for new drinks to survive. ${ }^{[20]}$
In addition, the Coca-Cola Company was once in a dilemma. As carbonated drinks contain a great deal of sugar, the Coca-Cola Company was the target of "an anti-obesity crusade". ${ }^{[19]}$ Therefore, healthier drinks like Zero coke were manufactured by Coca-Cola. ${ }^{[17]}$ Moreover, moral issues of Coca-Cola happened in India. The Coca-Cola Company extracted water from the groundwater resource which made water taste strange. Discharging waste water into the field and selling poisonous drinks to local people were also done by Coca-Cola. ${ }^{[10]}$ Hence, Coca-Cola performs their social responsibilities more often nowadays. For example, they had established 121 Hope Schools in

*Corresponding Author:

Yao Tong,

Dongbei University of Finance and Economics, No. 217, Jianshan Street, Shahekou District, Dalian, Liaoning, 116025, China; E-mail:18075398619@163.com. 
29 provinces around China by 2014..$^{[1]}$

Furthermore, Chinese people often give priorities to collective interests when individual benefits also exist. In the report of China's 19th National Congress of the Communist Party, President Xi stressed the importance of the public's interest not the benefits of top managers. ${ }^{[21]}$ What's more, he also highlighted that governments should unite people to establish a harmonious society. ${ }^{[21]}$ It is clear that the President Xi emphasized more on the collective welfare. Influenced by Chinese policies, Chinese people are inclined to concentrate more on group benefits.

In the following part, the author performed a SWOT analysis on the Coca-Cola Company. As for the argument part, the author argued the reasons why American beverage and individualism investment should be encouraged.

\section{Case Study}

\subsection{Research Topic}

Whether American beverage and individualism investment in China should be welcomed.

\subsection{Entity/Industry/Sector}

In this case study, the author wants to analyze how the Coca-Cola Company advertised in China. The case study contains four parts: analysis on strengths, weaknesses, opportunities and threats. As the first argument is about the ways that American beverage industry advertises enrich Chinese people's lives, the case study about one specific and representative American beverage company- $\mathrm{Co}-$ ca-Cola will support the first argument. Some data, for example the wonderful sales of Coca-Cola could be used in the first counter-argument to support that American beverage companies pose a threat to Chinese beverage corporates. Moreover, one of the Pepsi's brand imagesirreverence is an example to show American individualism and can also be used to support the second argument. Furthermore, some examples can be used in the introduction part to show the improvement of the Coca-Cola's CSR awareness.

\subsection{Strengths}

First of all, there are four major strengths when Coca-Cola Company promotes their products. Firstly, the Coca-Cola Company keeps in close contact with Chinese people. In the "Dream Forever" advertisement, Coca-Cola gave their best wishes to the Chinese national soccer team, which shortened the distance with Chinese consumers and stimulated the sales. ${ }^{[12]}$ Secondly, the Coca-Cola pays attention to Chinese major events and applies the event marketing strategy. For example, in 2008, special golden package Coke for the Beijing Olympic game were launched successfully into the market and then the transaction sales were increased by $29 \% .{ }^{[2]}$ Thirdly, Coca-Cola often have creative ideas which are based on the latest trend in China. Recently, "23 Coca-Cola limited-edition sleek cans that feature the people of China" has come into the market. ${ }^{[2]}$ These products demonstrate the concept of expressing people's personalities which fits young adults. One shopkeeper Ms. Gu recalled that more than $10 \%$ increase was seen in the Coca-Cola's sales when these new Cokes come into the market (see Appendix 1). Lastly, the Coca-Cola's advertisements which are full of positive energy pass this energy through media and make Chinese people feel more energetic. Aaron Smith demonstrated that the Coca-Cola has expressed its own unique brand images that are optimism, togetherness, diversity and inclusion. ${ }^{[18]}$

\subsection{Weaknesses}

However, weakness in flavors still exists in the Coca-Cola Company. Buffet who is also a shareholder of Coca-Cola Company advertised Cherry Coke last year. ${ }^{[20]}$ Though Buffet is quite popular among Chinese people and Cherry Coke is an attracting type of product that people want to have a try, the mix of cherry and coke actually doesn't suit Chinese people's flavors. ${ }^{[20]}$ Through the observation by the journalist Wei, the Cherry Coke can hardly be found in shopping centers. ${ }^{[20]}$ The shopkeeper Ms. Gu thought the failure of Coca-Cola is mainly caused by the incomplete understanding of Chinese people's flavors (see Appendix 1).

\subsection{Opportunities}

Furthermore, two main opportunities can be found in Coca-Cola Company. Above all, the Coca-Cola Company has always upgraded its product lines based on the trend. According to Ms. Huang, the vice president in the Asian-Pacific Coca-Cola Company predicted the trends for soft drinks which are health-focused, innovation in flavors and digital-based. Therefore, the Zero Coke and Coffee Coke were manufactured to fit consumers' needs. ${ }^{[17]}$ Moreover, Coca-Cola Company has claimed that more than 500 products have been planned to reduce sugar around the world. ${ }^{[15]}$ As for the digitalization, the Coca-Cola's first self-assisted AI refrigerator was put into Changsha this month to support its "520 Plan" ${ }^{[4]}$ In addition, Coca-Cola has performed its consumer social responsibilities (CSR) at full blast which gains recognition from increasing number of customers. According to the data in 2015, Coca-Cola has carried out nearly 20 programs to protect the water resource. 17.1 billion liters of water have been re- 
turned into the nature after their production. ${ }^{[24]}$ Taking the sustainable development into their consideration can show this company's awareness of social responsibility.

\subsection{Threats}

As for its threat part, fierce competition and a not bright future for carbonated beverages have been the main threats for the Coca-Cola Company. Firstly, competitions with Pepsi and Chinese local beverage companies have become fierce. In order to increase its market share, Pepsi established a strategic alliance with a popular company_-Tingyi Holding Corp in 2012. The Tingyi's strong sales network helped PepsiCo to distribute its products around the country. ${ }^{[9]}$ Moreover, Pepsi videoed a story about an actor who acts as the Monkey King in 2016 and more than 20 million views can be found in two weeks on many social platforms. Using the Monkey King's personality can demonstrate the Pepsi's brand image_—youth and irreverence successfully. ${ }^{[8]}$ Thus, Pepsi has challenged the Coca-Cola Company a lot by the agency of the viral marketing. Furthermore, since Coca-Cola had opened a pop-up store in 2017, the Chinese beverage brand Coco then also opened a pop-up store and made a huge success. ${ }^{\left[{ }^{16]}\right.}$ Secondly, a not promising future is for the carbonated beverage industry. According to the data released by the China beverage industry association, the sales of carbonated beverages declined $2.35 \%$ in $2016 .{ }^{[20]}$ China quality association released the "general satisfaction index of beverage industry in 2016" which reported that the low level of satisfaction of carbonated drinks is because beverage corporates only rely on consumers' drinking habits to maintain their sales. ${ }^{[20]}$

\subsection{Analysis of Data}

In this case study, the author mainly analyzes the ways that the Coca-Cola Company advertised in China. The case study contains four parts: analysis on strengths, weaknesses, opportunities and threats. Compared to its weakness, much more strengths can be found in Coca-Cola. In addition, Coca-Cola always follows the latest trend and keeps itself updated. Nevertheless, a not bright future may be seen in the whole carbonated beverage industry. Based on this case study, the author found that keeping updated to the latest trend, caring customers' needs and fulfilling their CSR are the Coca-Cola's main keys to success.

\section{Argument}

Although the future of new drinks is not bright and Chinese beverage market is getting more mature, Coca-Cola and many other beverage companies have promoted their products at full blast. Moreover, Chinese people tend to care more about group benefits than their own interests. As such, American investment in China should be welcomed because the advertising strategies the American beverage industry uses enrich Chinese people's lives, and there are benefits from experiencing the American value of individualism when Chinese employees work.

In the first place, the ways that American beverage industry uses to advertise enrich Chinese people's lives because of their advocacies and awareness of social responsibilities. Firstly, what American beverage enterprises advocate has a positive impact on Chinese people's daily lives. For example, one of Coca-Cola's successful slogans: open happiness which passes the positive energy to the audience and makes them more energetic. ${ }^{[5]}$ Moreover, apart from the home and office, Starbucks aims to become the third place in people's lives. Providing the comfortable social sites, Starbucks hopes people can socialize with each other comfortably there. ${ }^{[7]}$ Secondly, some CSR commitments of these beverage companies may arouse people's awareness about social responsibilities. For example, since the Budweiser Company is aware of the bright future of renewable electricity, so it promised that "every Budweiser around the world will be brewed with $100 \%$ renewable electricity by $2025 .{ }^{\text {"[3] }}$ These behaviors can raise people's awareness of sustainable development.

However, some people argued that the success of American beverage companies may threaten Chinese local beverage enterprises. Consumer Culture Theory (CCT) demonstrates a successful method of selling products which is to give commodities a specific (social) meaning and encourage them to purchase by making them accept their brand image. ${ }^{[1]}$ Due to the successful slogans, massive people may have a deep impression on their brands. In 2008, the golden package Coke has prompted the transaction sales to increase by $29 \%$ because it celebrated this event with Chinese people just like their old friends which made Chinese consumers feel warm and thereby endorsing the Coca-Cola. ${ }^{[22]}$ Thus, they think that more and more people are likely to buy American beverages rather than Chinese beverages. In fact, these statements are true and Chinese people have to admit threats truly exist. Owing to the globalization, the local economy in the developing country-China will suffer some negative impacts inevitably. However, it is the competitions even the challenges that force the companies to release their potential. These challenges are called challenge stressors which can be acknowledged as chances for growth and achievement. ${ }^{[6]}$ For instance, because of the popularity of pop-up stores, Coca-Cola has opened a pop-up store using celebrity ef- 
fect in Zhengzhou in 2017, which captured lots of media. ${ }^{[23]}$ Then in 2018, Coco Company made good use of hot topic and held a creative "My Ideal Boyfriend" pop-up store in Shanghai, which attracted more than 15000 people to participate in these activities. These innovations which are based on Coca-Cola's pop-up store ideas have achieved a huge success. ${ }^{[16]}$

Furthermore, American individualism value makes Chinese employees focus on improving their own abilities, thereby becoming more competent. To begin with, individualism refers to the thought that the important things are the interests of their own and people who are close to them. They also care more about task than relationship. ${ }^{[13]}$ In the International Management, the score of United States in individualism is 67 , which proves that America has a high individualism. In Hofstede's Cultural dimensions, people with high individualism tend to have "greater individual initiatives". People can image that Chinese employees with high individualism would prefer to work alone and therefore need to be relatively capable to achieve the goals. In fact, many slogans of American companies also demonstrate the American individualism. For example, one perceived value of American company Pepsi__ irreverence which showed a focus on their own freedom is one specific example of US's individualism. ${ }^{[8]}$

On the other hand, some critics claimed that although American individualism value can help make employees competent, it is incompatible with the organizational culture of most Chinese enterprises because most Chinese people emphasize more on the collectivism. If they still insist voting for the individualism, relationship confliction may be occurred. Collectivism refers to "the tendency of people to belong to groups or collectives and to look after each other in exchange for loyalty." ${ }^{,[14]}$ The findings showed that China has the score of 54 in the individualism. ${ }^{[14]}$ The low individualism (high collectivism) demonstrates that Chinese are more willing to work in groups rather than work alone. ${ }^{[14]}$ Relationship conflicts set off when disagreements about personal values and interpersonal relationships and other incompatible things happen. ${ }^{[6]}$ Therefore, employees with individualism may not get on well with others owing to the different perceived values and thus cause the relationship conflict. As a consequence, this kind of conflict may harm the tem process. However, defenders argued that it is quite common for team members to have conflicts because of difference in value. They used the Four Stage Theory to demonstrate that the conflict caused by value is quite common in the team development. ${ }^{[6]}$ In the second stage_— storming, members insist taking their original ideas into their teams, which may cause conflicts and do harm to the progress. In con- trast, in the next stage_—norming, group members start to collaborate with each other. Despite the conflict at the beginning, cooperation will be the final outcome of team process. Moreover, they also illustrated that since nearly everyone needs to work in teams regardless of individualism or not. According to Colquitt, Lepine and Wesson (2009), cognitive ability tends to be highly correlated with task performance. ${ }^{[6]}$ Hence, these team members with high individualism often have high level of cognitive ability and they can actually improve the organizational performance to some extent.

In conclusion, American investment of beverage companies and individualism value should be welcomed because the advertising of American beverage companies makes Chinese people's lives colorful and Chinese employees can gain a lot from American individualism on their work.

\section{Conclusion}

In this essay, there are three main parts: literature review, case study and argument. In the literature review, five sections are being talked about. Moreover, in the case study, how the Coca-Cola advertises in China is mainly talked about. In addition, in the argument section, the author argued that American investment of beverage companies and individualism value should be encouraged because the advertising of American beverage companies enriches Chinese people's lives and Chinese employees can benefit a lot from experiencing the American individualism on their work. After reading this essay, the author recommends two research orientations for future reading. One is the cooperation between American beverage companies and Chinese local drinks enterprises. The other one is the tactics that managers apply to deal with culture differences within the teams.

\section{References}

[1] Arnould J., \& Thompson J. (2005). Consumer culture theory (CCT): Twenty years of research. Journal of consumer research, 31(4), 868-882.

[2] Brandchannel. (2018). Coca-Cola Tests Augmented Reality 'Sleek Cans' in China. Retrieved from http:// www.brandchannel.com/2018/04/19/coca-cola-china-city_sleek_cans_augmented_reality/

[3] Budweiser. (2016). Our goal: renewable 100\% electricity. Retrieved from http://renewablefuture-homolog.adttemp.com.br/\#about-the-movement

[4] Coca-Cola. (2018). Coca-Cola and JD.com opened a convenience store in Changsha for the "520 plan." Retrieved from https://www.coca-cola.com.cn/sto- 
ries/wltkkklhjdklyjbld

[5] Coca-Cola. (2016). Some wonderful Coco- cola advertisements that we have missed. Retrieved from https://www.coca-cola.com.cn/stories/nxnwmegdklk$\operatorname{lggy}$

[6] Colquitt J., Lepine J., \& Wesson M. (2009). Organizational Behavior: essentials for improving performance and commitment. Dalian, China: Dongbei University of Finance \& Economics Press.

[7] Dollinger M. (2008). Starbucks, "The Third Place", and Creating the Ultimate Customer Experience. Retrieved from https://www.fastcompany.com/887990/ starbucks-third-place-and-creating-ultimate-customer-experience

[8] Gianatasio D. (2016). Pepsi Has a Huge Hit in China With This Fascinating Ad About the 'Monkey King' Family. Retrieved from https://www.adweek.com/ creativity/pepsi-has-huge-hit-china-fascinating-adabout-monkey-king-family-168946/

[9] Ho L. (2013). PepsiCo's strategy wins market share. Retrieved from http://www.globaltimes.cn/content/829870.shtml

[10] India Resource Center. (n.d.). Campaign to Hold Coca-Cola Accountable. Retrieved from http://www. indiaresource.org/campaigns/coke/

[11] Journey Staff. (2014). Celebrating 35 Years of Coca-Cola in China. Retrieved from https://www.coca-colacompany.com/stories/celebrating-35-years-ofcoca-cola-in-china

[12] Kong X. (n.d.). The study of Coca-Cola's advertising strategies in China. Retrieved from https://www. xzbu.com/1/view-5217707.htm

[13] Koontz H., \& Weihrich H. (2010). Essentials of Management: An International Perspective (8th ed.). Dalian, China: Dongbei University of Finance \& Economics Press.

[14] Luthans F., \& Doh J. (2016). International Management: Culture Strategy and Behavior (8th ed.). Beijing, China: China Machine Press.

[15] Moye J. (2017). Quincey at CAGNY: We Are Going to Be a Total Beverage Company. Retrieved from https://www.coca-colacompany.com/stories/quinceyat-cagny-we-are-going-to-be-a-total-beverage-company

[16] News.ifeng.com. (2018). The activities in Coco stores can make you fall in love with them. Retrieved from http://news.ifeng.com/a/20180119/55295293_0. shtml

[17] Qi. (2018). Coca-Cola's vice president of Asian-Pacific companies Ms. Huang: the analysis about the creative trend of Chinese Ready-to-Drink industry. Retrieved from http://www.chinacenn.com/qwfb/ zjjx/20180527/123074.html

[18] Smith A. (2018). Coca-Cola's Super Bowl ad stays on trend, focuses on diversity. Retrieved from http:// money.cnn.com/2018/02/01/news/companies/coca-cola-super-bowl/index.html

[19] Tinker B. (2013). Coca-Cola weighs in on obesity fight. Retrieved from https://edition.cnn. com/2013/01/14/health/coke-obesity/index.html

[20] Wei W. (2017). Coca-Cola has launched the Cherry Coke and Ginger Cola. What kinds of weird drinks have you tried? Retrieved from http:/www.chinanews.com/life/2017/05-04/8215092.shtml

[21] Xinhua Press. (2017). The nineteenth report of the Communist Party. Retrieved from http://language.chinadaily.com.cn/19thcpcnationalcongress/2017-11/06/ content_34188086.htm

[22] Yang L. (n.d.). Things we can learn from the Coca-Cola's successful marketing during the Beijing Olympic Games. Retrieved from https://www.xzbu. com/2/view-6033764.htm

[23] Zhang X. (2017). Zhengzhou held the first Lu Han theme pop-up stores in He Nan Province. Retrieved from http://newpaper.dahe.cn/hnsb/html/2017-08/03/ content_172732.htm

[24] Zhuan T. (2015). Coca-Cola meets 2020 water goal in China. Retrieved from http://www.chinadaily.com. cn/cndy/2015-06/18/content_21037422.htm 